\title{
VALUE OF SERVICES FOR PASSENGER IN PUBLIC TRANSPORT - THEORETICAL APPROACH
}

\section{ZUZANNA KŁOS-ADAMKIEWICZ}

University of Szczecin, Faculty of Management and Economics of Services, POLAND e-mail: zuzanna.klos@wzieu.pl

\begin{tabular}{l|l}
$\begin{array}{l}\text { RECEIVED } \\
\text { ACCEPTED }\end{array}$ & $\begin{array}{l}4 \text { December } 2017 \\
5 \text { January } 2018\end{array}$ \\
JEL & R41 \\
KEYWSIFICATION & transport services, public transport, value of services \\
ABSTRACT & $\begin{array}{l}\text { The definition of the value of transport services for passenger is not easy to determine. Knowledge of the speci- } \\
\text { ficity of public transport as well as the general features of transport services makes existing definitions of value, } \\
\text { that refer to products more often than to services, constrain the ease of its understanding. Therefore, for the } \\
\text { purposes of this article, definitions of value including value for passenger and their understanding in the context } \\
\text { of public transport services are presented. It was pointed out that this value should be shaped mainly from the } \\
\text { point of view of the passenger, who, having a choice of different means of transport and their specific features, } \\
\text { will choose the one to be used for everyday trips. }\end{array}$
\end{tabular}

\section{Introduction}

Public transport is part of the city's transport system. The system consists of the following subsystems: technical, organizational and economic-legal (Grzywacz, Burnewicz, 1988). City's transport system ${ }^{1}$ constrain to

${ }^{1}$ The transport system is characterized by a certain degree of atomization, meaning that there are potentially many possibilities to configure its elements (Downar, 2006). 
specific area, where different means of transport are being used (see: Rydzkowski, Wojewódzka-Król, 2007):

- inidividual, i.a..: bicycle, motorbike, taxi, passenger car,

- group (used along with other passengers) i.a.: microbus, taxi, passenger car,

- collective, i.a.: bus, trolleybus, tram, metro, regional and urban rail.

Elements of the city's transport system can be distinguished, among others, due to the subject of carriage (passengers and goods), branch of transport (road, rail, water) as well as accessibility for transport users (public and individual). According to the Act of public collective transport, the broadest term is collective public transport meaning "publicly available, regular transport of people carried out at specified intervals and on a specific communication line, communication lines or communication network", whereas urban transport is "municipal passenger transport within administrative borders of the cities or: cities and municipalities, cities or neighbouring municipalities and municipalities" (Act on public transport, 2010).

The role of public transport ${ }^{2}$ in this system has changed over time, especially due to the growing usage of passenger cars. The car, which is not only a mean of transport, has also become a symbol of independence, freedom and prestige. On the other hand, collective transport, through the implementation of assumptions related to the sustainable development of transport in the cities, is the form of transport that has an impact on improving the quality of life in the city, reducing congestion, and reducing investment expenditures related to road infrastructure. Awareness of the advantages resulting from the development of this form of transport is easier to understand through the prism of the costs, hardships and sacrifices of people using cars, condemned to road congestion, resulting from the growing use of passenger cars for daily travels. The requirements of residents regarding travelling time or reaching the goal of their journey, in the case of a growing congestion puts into question the usefulness of a passenger car. Nevertheless, attention should be paid to the fact that the use of passenger cars in everyday journeys is, in some cases, hard to replace, above all- the need to accomplish many travel destinations in a short time (e.g. transport of family members to educational institutions, to work or other places). In this case, the usability of the passenger car is much higher and it is difficult to expect that this group of people completely give up using this mean of transport. For car users, the problems are parking fees in designated zones in the city centre, restricted traffic zones, problems with finding a parking space or fuel prices. However, in other cases, a real alternative to car usage is public transport or, on a widening scale - bicycle.

\section{Value of services - basic definitions}

The concept of value of services is not easy to define. The analysis of the literature on this subject indicates the existence of many concepts concerning value that are more or less interrelated, but should not be used interchangeably. These include: value, added value, value for customer, customer value, perceived value, value-inuse and usability.

Based on the analysis of available Polish and foreign literature in the field of theory of value, definitions of selected terms were adopted for the purposes of the article, which will clarify further considerations.

There are different understandings under the concept of value. Depending on the author, its definition might be approached differently. Throughout the history of economic development as a science, this category has been

2 In the article adopting a more general description of the phenomena described, the most common is public transport. The emergence of replacement terms (i.a. urban transport) resulted from understanding these concepts in a similar way, referring to public transport in the cities. 
interpreted differently. Economists more often use the word value in a general, subjective or colloquial sense. The value can be interpreted in material terms, where the feature can be expressed by monetary or other means of payment. It can also constitute a set of features that determine the value of a given thing and its importance for individual people, as well as a number specifying how many units the given physical quantity contains (value understood from the prism of the price) (Zadora, 2004). In relation to this lack of a firm definition, it is meaningful to speak about the value of something, e.g. added value, customer value, value for the customer or value-in-use.

Nowadays an important element of competitiveness on the market is the management of added value of products and services. The added value can be called a feature that differentiates material products or services from each other, thus creating an additional benefit for the customer. Added value is what causes a given product or service to be perceived by the client as more desirable (Biznes. Słownik pojęć ekonomicznych, 2006). The concept of added value covers everything that goes beyond the quality of a given service, in this case - the transport service. The added value according to W. Bakowski is higher quality at a satisfactory price. Often the added value determines the choice of a particular service (Blaug, 2000).

Presentation of the interpretation of subsequent concepts regarding value requires a reference to the specifics of the transport service. Transport production, which has not material nature, means that the product of transport activity is a service, and the production process has functional nature. The lack of material nature of transport production and unity with consumption differentiate transport activities from the production of goods and, thus, affect the nature of the transport services market (Grzywacz, Burnewicz, 1988). Transport services that exist on the market and being traded have the characteristics of goods, that is why the value of those services might be shaped.

The following economic categories are linked to the concept of value: customer value and value for the customer. The customer value is understood as the value of all streams that customers generate to the company, less the costs associated with providing it to the clients. These streams include: cash inflows, profitability (by acceptable prices) and information about their needs, opinions about the product, experiences with the company, brand, personnel and information on competition (Dobiegała-Korona, Doligalski, 2011) .

In relation to transport, and more specifically- public transport - a passenger who is also a customer is the source of cash inflow to the city budget. The city also funds the budgets of carriers (operators) as compensation ${ }^{3}$ for lost revenues or incurred costs. However, the passenger is a source of income and at the same time he represents value in the city's mass transport system. One of the definitions of the value for the client is presented by R. Woodruff, who acknowledges that "these are the customer's preferences and perceptions about product attributes, attributes of its functioning and consequences resulting from its use, which enable (or prevent) reaching the client's goals and intentions in the process of use "(1997, for: Zadora, 2004).

The value for the customer is also defined by $\mathrm{Ph}$. Kotler as the difference "between the total value for the customer and the total cost to the customer. The total value for the customer is a bundle of benefits expected by the customer in relation to a given product or service. The total cost for the customer is a bundle of costs that customers expect when assessing a product or service, their purchase and use"(Kotler, 1997).

${ }^{3}$ Compensation, i.e. cash or other property benefits granted to the public transport operator, in connection with the provision of public transport services. Dz.U. 2011, nr 5, poz. 13. Ustawa z dnia 16 grudnia 2010 r. o publicznym transporcie zbiorowym. 
In passenger transport, the value for the customer, i.e. the passenger, are the features that make up this value. The customer evaluates the product ${ }^{4}$ and its value according to his own criteria, which include many, also non-measurable product features (intangible features such as fashion, relish, colour or brand) (Bakowski, 2010).

When considering a value for a customer, it is necessary to distinguish the value that he expects from the one he receives. The value expected by the customer is defined as "the surplus of the customer's perceived benefits and costs associated with the use of a given service or product" (Stabryła, 2011). This is closely related to the utility of consumer decisions and affects the client's market choices. Passenger value assessment is subjective, which is why it is perceived value, not actual.

Among the features of the concept of value for the client, the most significant is subjectivity and relativism, because these features make it difficult to indicate the universal concept of creating value for the passenger. However, support for the process of defining it, is greatly facilitated in the case of studies of preferences and travel behaviour. In addition, situational conditions cause that the value assessment is variable over time. The multidimensionality and dynamism of perceiving value are a hindrance due to the possibility of rapid changes, especially when competing with car usage. The value is ambiguous and imprecise, directly immeasurable and it is not the subject to standardization, which makes it difficult to define in proper way and indicate factors that influence its increase (see also: Cole Preston, 2006).

\section{Value of services for passenger in public transpopt}

Multitude and diversity of users' needs - who are current and potential public transport passengers forces public transport organizer in the city to be flexible and shows the need to adjust the offer. Determining the value of the service through the features of the public transport offer is possible mainly due to research on the preferences and transport behaviour of the city's residents. Public transport services, which are services of general interest, also mean that transport companies cannot treat the value of their services as a determinant of competitive position (which in this case is not taken into account), as well as profit growth.

In order to increase the number of public transport passengers, its services must be more valuable for the passengers than traveling by own car. Identification and hierarchization of factors that affect the behaviour of transport users should be translated into actions aimed at increasing the value.

In the case of making a decision regarding the choice between public transport and a car, priority is given to price and quality as the basic attributes of the value for passenger, but additional elements of this value, such as information, availability or experience might help in decision making (Figure 1).

The most important elements of the value for client include the attributes of the purchased transport service (mainly quality, price and delivery time), the image of the transport company, where experience in providing services is very important and the level of trust of users in the brand, as well as openness to customer relations (including consultancy and providing detailed information).

${ }^{4}$ According to W. Bąkowski, the product of public transport is a public transport line with its elements, i.e. the beginning and the end, the construction, the number of stops, the timetable, the frequency of running and the set of vehicles assigned to operate this line. See: Bąkowski (2010), p. 222. 


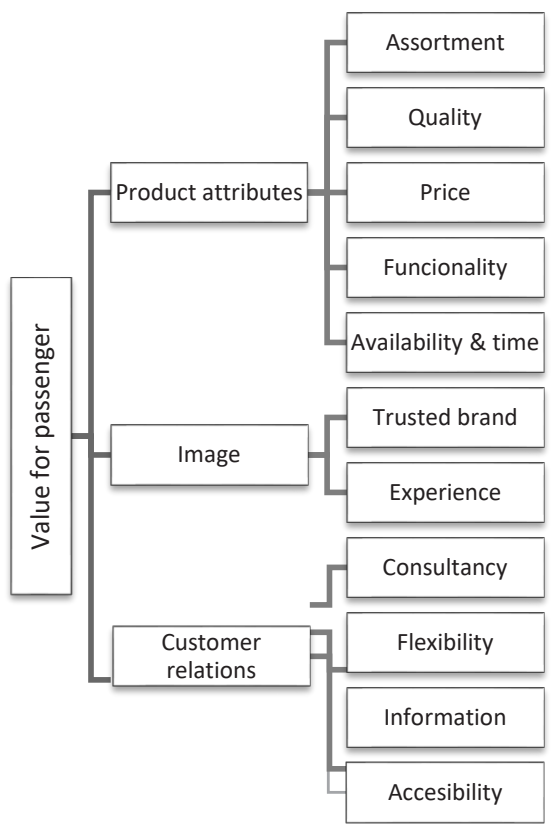

Figure 1. Elements of value for passenger

Source: own elaboration based on: Bąkowski (2010), p. 223.

V. Zeithalm emphasizes that the value is subjective, and its perception depends on the situation, while the price is an important criterion, but has a different impact on customers (1988). Another definition of value is quoted by K. Monroe: "Value perceived by buyers is a ratio between the quality or benefits perceived by them in the product and the price they have to pay for it" (1990). Thus, the increase in the perceived value for the customer can occur in two ways: by increasing the benefits that client experiences or reducing the costs he bears. The perceived benefits are related to the product, service, personnel or image, while the costs incurred by the client are the sum of all costs (cash and non-cash) related to the purchase of a marketing offer (Dyr, 2009, p. 173). The passenger, who is also a customer, considers the value in relation to a specific transport service, taking into account several additional features, in addition to the quality of the service, which include access to the bus stop (distance, time of arrival) or access to the vehicle (ease of entry, ease of occupancy, etc.). Moreover, the accessibility features resulting from customer relations are taken into account, such as: obtaining information on transport services, journey scheme and their prices, ticket purchase technology (e.g. e-ticket). Another important element is the price of the service, which is also compared with the value of traveling with your own car (Dyr, 2009). The concept of the value of a transport service is according to the classic formula of $\mathrm{K}$. Marks transfer of a specific objectified value and necessary work related to it, the result of which is the creation of a new value for society in the form of the production of transport services. In the case of public transport, as a result of service accomplishment, its value raises according to the possibility of relocation (Grzywacz, Burnewicz, 1988).

The value category is inseparable from the concept of value-in-use. Work that creates value through the production of goods and services without creating added value is impossible. Value is the social side of the 
transport service, and the value-in-use is its second, material side. The utility value of a transport service in public transport is, according to W. Grzywacz, the same movement, "...which manifests itself in the change of the location of people transported in space, enabling the achievement of a useful purpose". Utility value of transport gives an additional attribute of the utility of the place, the possibility of using it or using the activities of individual people (Grzywacz, Burnewicz, 1988). The concept that requires explanation is also usability. According to W. Grzywacz, it is "a subjective assessment of the level of fulfilling the transport needs from the point of view of specific postulates or a specific service recipient” (Grzywacz, Burnewicz, 1988).

\section{Evaluation of the value of the services for passengers}

The assessment of the value of the transport service for the customer through the prism of its features makes it possible to make a decision regarding the choice of a particular means of transport. The high value of the service is a factor that can influence the passenger's decision regarding the choice of public transport, while its decline increases the interest in using the passenger car, especially for people who can make this choice (owners or car users). Competition between forms of movement is quite unusual. W. Bąkowski drew attention to this, formulating research problems for the scientific discipline of transport economics (2010):

- what categories should be used to evaluate public transport products to make their assessment and be able to compete by value?

- what actions should be taken on the supply side (network, rolling stock, timetables, information, tickets and price) that will increase the value of public transport products?

Ability to offer users the value they expect, it is necessary to first know their needs. In the case of a transport service, where the basic purpose is the need to move, the characteristics of collective and individual transport decide on the choice of a particular form of movement. The passenger is interested in the effect that can be achieved when using the chosen service. The perceived value is largely the result of knowledge about services, and not the services themselves, which serve as an instruments satisfying the needs of clients (Buttle, 2011).

The growing needs in terms of the quality of mass transport services require public transport organizers to shape the value of a transport services at the level that will satisfy current and future passengers and will prompt resignation from daily travels made by car. While a certain group of residents (due to the lack of an alternative), regardless of the quality, price or availability of public transport is forced to use its services, people who have an alternative should be encouraged to choose public transport. Shaping the value of the services is therefore mainly directed to those who can travel by their own car, but when the offered urban transport service suits them in terms of price and quality, they are willing to use it. Up against the necessity to meet the daily travel requirements of residents, it is necessary to shape the value of the transport services in such a way that the need for mobility is met, while maintaining the appropriate quality in relation to the price.

\section{Conclusions}

Based on the definitions quoted in the article, it can be assumed that the concept of value expresses the level of satisfaction from using public transport services perceived and assessed by the passenger, which results from the total cost incurred to achieve the goals, objectives and benefits associated with using the service. The passenger evaluates this value according to subjective criteria, depending on the situation and related to the expected benefits 
and costs. Perception of the value of the service for public transport passenger also depends on comparing it with the value of travel using other means of transport.

In many cases, the value of public transport services affects the communication behaviour of city residents, but only in conditions that allow the use of appropriate tools related to the concept of a new culture of mobility, which relate to all ways of moving around the city.

\section{References}

Barnes, C., Blake, H., Pinder, D. (2011). Creating and delivering your value proposition: managing customer experience for profit. Londyn: Kogan Page Publishers.

Bąkowski, W. (2010). W poszukiwaniu oceny wartości usługi w miejskiej komunikacji zbiorowej. Problemy Transportu i Logistyki, 13. Zeszyty Naukowe Uniwersytetu Szczecińskiego, 628.

Bijoch, K., Redeł, S. (2000). Prawo gospodarki komunalnej. Warszawa: Wydawnictwo Naukowe PWN.

Biznes. Słownik pojęć ekonomicznych (2006). Warszawa: Wydawnictwo Naukowe PWN.

Blaug, M. (2000). Teoria ekonomii: ujęcie retrospektywne. Warszawa: Wydawnictwo Naukowe PWN.

Buttle, F. (2011). Customer Relationship Management. Concepts and Technologies. Burlington, Ma, USA: Elsevier Ltd.

Cole, M., Parston, G. (2006). Unlocking Public Value. A New Model for Achieving High Performance in Public Service Organizations. New Jersey-Hoboken: John Wiley \& Sons, Inc. Publishing.

Dobiegała-Korona, B., Doligalski, T. (eds.) (2011). Zarządzanie wartością klienta w przedsiębiorstwach w Polsce. Warszawa: Oficyna Wydawnicza Szkoły Głównej Handlowej w Warszawie.

Downar, W. (2006). System transportowy. Kształtowanie wartości dla interesariusza. Szczecin: Wydawnictwo Naukowe Uniwersytetu Szczecińskiego.

Dyr, T. (2009). Czynniki rozwoju rynku regionalnych przewozów pasażerskich. Radom: Wydawnictwo Politechniki Radomskiej.

Grzywacz, W., Burnewicz, J. (1988). Ekonomika transportu. Warszawa: Wydawnictwo Komunikacji i Łączności.

Kotler, Ph. (1997). Marketing Management. Analysis, Planning, Implementation and Control, 9th edition. New Jersey: Prentice-Hall International, Inc., Upper Saddle River.

Monroe, K. (1990). Pricing: Making Profitable Decisions. New York: McGraw-Hill.

Rydzkowski, W., Wojewódzka-Król, K. (ed.) (2007). Transport. Warszawa: Wydawnictwo Naukowe PWN.

Stabryła, A. (ed.) (2011). Przegląd problemów doskonalenia systemów zarządzania przedsiębiorstwem. Encyklopedia zarządzania. Kraków: Wydawnictwo Mfiles.pl.

Ustawa z dnia 16 grudnia 2010 r. o publicznym transporcie zbiorowym. Dz.U. 2011, nr 5, poz. 13.

Woodruff, R. (1997). Customer Value: The Next Source for Competitive Advantage. Journal of the Academy of Marketing Science, $25(2)$.

Zadora, H. (ed.) (2004). Wartość w naukach ekonomicznych. Gliwice: Wydawnictwo Politechniki Śląskiej.

Zeithaml, V. (1988). Consumer perceptions of Price, Quality, and Value: A Means-End Model and Synthesis of Evidence. Journal of Marketing, 52 (3).

Cite this article aS: Kłos-Adamkiewicz, Z. (2018). Value of services for passenger in public transport - theoretical approach. European Journal of Service Management, 1 (25), 125-131. DOI: 10.18276/ejsm.2018.25-15. 